\title{
Tachykinin $\mathrm{NK}_{2}$ receptors and enhancement of cholinergic transmission in the inflamed rat colon: an in vivo motility study
}

\author{
${ }^{*, 1}$ F. Carini, ${ }^{1}$ A. Lecci, ${ }^{1}$ M. Tramontana, ${ }^{1}$ S. Giuliani \& ${ }^{1}$ C.A. Maggi \\ ${ }^{1}$ Department of Pharmacology, Menarini Ricerche, via Rismondo 12/A, 50131, Florence, Italy
}

1 In the gastrointestinal tract, tachykinin $\mathrm{NK}_{2}$ receptors are localized both on smooth muscle and nerve fibres. $\mathrm{NK}_{2}$ receptor antagonists reduce exaggerated intestinal motility in various diarrhoea models but the site of action contributing to this effect is unknown. In this study we investigated the effects of atropine $\left(1.4 \mu \mathrm{mol} \mathrm{kg}{ }^{-1}\right.$, i.v.), hexamethonium $\left(13.5 \mu \mathrm{mol} \mathrm{kg}^{-1}\right.$, i.v.), and nepadutant $\left(0.1 \mu \mathrm{mol} \mathrm{kg}{ }^{-1}\right.$, i.v. $)$, a selective tachykinin $\mathrm{NK}_{2}$ receptor antagonist, on distension $(0.5$ and $1 \mathrm{ml})-$, or irritation (acetic acid, $0.5 \mathrm{ml}$ of $7.5 \% \mathrm{v} \mathrm{v}^{-1}$ )-induced motility in the rat distal colon in vivo. The effects of atropine, hexamethonium or $\mathrm{N}^{\omega}$-nitro-L-argininemethylester (L-NAME, $1.85 \mu \mathrm{mol} \mathrm{kg}^{-1}$, i.v.) on $\left[\beta \mathrm{Ala}^{8}\right] \mathrm{NKA}(4-10)\left(10 \mathrm{nmol} \mathrm{kg}{ }^{-1}\right.$, i.v.)-induced colonic contractions were also investigated. 2 When the colonic balloon was filled with a subthreshold volume $(0.5 \mathrm{ml})$, the intraluminal instillation of acetic acid triggered a high-amplitude phasic colonic motility which was partially reduced by nepadutant and suppressed by either hexamethonium or atropine. Filling of the balloon with $1 \mathrm{ml}$ evoked reflex (hexamethonium-sensitive), atropine-sensitive phasic colonic motility: nepadutant had no significant effect on the distension-evoked motility.

3 Neither hexamethonium nor atropine significantly reduced [ $\left.\beta \mathrm{Ala}^{8}\right] \mathrm{NKA}(4-10)$-induced colonic contractions, whereas nepadutant suppressed them. Following L-NAME pretreatment, $\left[\beta \mathrm{Ala}^{8}\right] \mathrm{N}-$ KA(4-10)-induced colonic contractions were inhibited by both atropine and hexamethonium. In hexamethonium-pretreated animals, an atropine-sensitive component of $\left[\beta \mathrm{Ala}^{8}\right] \mathrm{NKA}(4-10)$-induced colonic contractions was also evident.

4 These results indicate that the application of irritants onto the colonic mucosa induces the release of endogenous tachykinins which enhance excitatory cholinergic mechanisms through the stimulation of $\mathrm{NK}_{2}$ receptors.

British Journal of Pharmacology (2001) 133, 1107-1113

Keywords: Nepadutant; atropine; hexamethonium; L-NAME; colitis; distension; inflammation; compliance; muscarinic receptors; nicotinic receptors

Abbreviations: AUC, area under the curve; L-NAME, $\mathrm{N}^{\omega}$-nitro-L-argininemethylester; MAC, maximal amplitude of contractions; $\mathrm{MP}$, minimal pressure; NKA, neurokinin A; $\mathrm{NK}_{2} \mathrm{r}$-ir, $\mathrm{NK}_{2}$ receptor immunoreactivity; NOS, nitric oxide synthase; SP, substance P

\section{Introduction}

Acetylcholine and tachykinins are the main mediators supporting excitatory neuromuscular transmission in the gastrointestinal tract. They are co-stored in intrinsic excitatory motor neurons of the myenteric plexus and play a pivotal role in the ascending excitatory reflex and intestinal peristalsis (see Holzer \& Holzer-Petsche, 1997 for a review; Holzer et al., 1998). Tachykinins (in the intestine, mainly substance P, SP, and neurokinin A, NKA) exert their biological effects through the stimulation of three different receptors termed tachykinin $\mathrm{NK}_{1}, \mathrm{NK}_{2}$ and $\mathrm{NK}_{3}$ (Maggi, 1995). In vitro studies indicated that the selective stimulation of all the three tachykinin receptors elicit direct or nervemediated myotropic effects in the rat intestine, (Holzer \& Holzer-Petsche, 1997); in the rat colon, part of these contractile effects involve the activation of cholinergic mechanisms (Chang et al., 1991). In particular, contractions elicited by NKA (which is a potent agonist at both $\mathrm{NK}_{1}$ and $\mathrm{NK}_{2}$ receptors) in rat colon in vitro were reduced by atropine

*Author for correspondence: E-mail: alecci@menarini-ricerche.it but not by tetrodotoxin suggesting the presence of facilitatory tachykinin receptors on cholinergic nerve terminals (Chang et al., 1991). Accordingly, in vivo studies have determined that meal transit in the rat intestine was enhanced by low doses of NKA in an atropine-sensitive manner (Holzer, 1985). Immunohistochemical studies have detected the expression of the three tachykinin receptors in the rat gastrointestinal tract: a significant portion of $\mathrm{NK}_{2}$ receptor immunostaining $\left(\mathrm{NK}_{2} \mathrm{r}\right.$-ir) was localized on nerve terminals in both myenteric and submucosal plexuses (Grady et al., 1996). Interestingly, in the myenteric plexus $\mathrm{NK}_{2} \mathrm{r}$-ir was also identified on nitric oxide synthase (NOS)-ir inhibitory interneurons (Portbury et al., 1996), whereas in muscle layers $\mathrm{NK}_{2} \mathrm{r}$-ir colocalized in nerve fibres expressing SP, suggesting the presence of these receptors on terminals of cholinergic motor neurons (Vannucchi et al., 2000).

It is also known that $\mathrm{NK}_{2}$ receptors can support atropineresistant intestinal reflex contractions both in vitro (Holzer et al., 1998) and in vivo (Giuliani et al., 1993; 1996; Lecci et al., 1998). In vivo studies with selective $\mathrm{NK}_{2}$ receptor agonists and antagonists have highlighted a role for these receptors in 
the enhancement of rat intestinal propulsion during inflammatory conditions (Tramontana et al., 1994; Croci et al., 1994; 1997), however it has not been determined yet whether this effect was due to a modulation of cholinergic mechanisms or to a direct neuroeffector role exerted by NKA during inflammation.

In order to address this question, this study investigates the effect of the selective tachykinin $\mathrm{NK}_{2}$ receptor antagonist nepadutant, formerly MEN11420 (Lecci et al., 1997), the non selective muscarinic antagonist atropine, or the ganglionic nicotinic receptor antagonist hexamethonium on colonic motility elicited by distension or local irritation induced by intrarectal administration of acetic acid in anaesthetized rats. The effects of cholinergic antagonists was also determined on colonic contractions induced by a selective $\mathrm{NK}_{2}$ receptor agonist, in the absence or in the presence of a NOS inhibitor, to assess whether there is a cholinergic component in the contractile responses mediated by $\mathrm{NK}_{2}$ receptor stimulation.

\section{Methods}

\section{General}

Male Wistar rats (Charles River, Calco, Italy) weighing 350$400 \mathrm{~g}$ were used throughout the study; they had free access to water until the day of experiment and to food until the day before. Animals were anaesthetized with urethane $\left(1.2 \mathrm{~g} \mathrm{~kg}^{-1}\right.$ s.c.) and the left jugular vein was cannulated with a polyethylene catheter (PE 50) for drug administrations. Fecal pellets were hand-pushed out from the distal colon by gentle pressure exerted through the skin in the cephalo-caudal direction. Afterwards, a polyethylene catheter (PE 50) for acid acetic or saline instillation and a latex balloon (approximate length $2 \mathrm{~cm}$ when empty, capacity $>1.5 \mathrm{ml}$ ) tied to another polyethylene catheter (PE 90) were inserted through the anus into the rectum for 7 and $5 \mathrm{~cm}$ respectively, and secured to the tail in order to avoid the propulsion of the balloon and catheters. The balloon-catheter was connected to a pressure transducer and the intraluminal colonic pressure was recorded with a polygraph integrated with a MacLab apparatus. The balloon was filled with $0.5 \mathrm{ml}$ of water and basal colonic motility was recorded during a period of $45 \mathrm{~min}$ (basal pre-stimulus).

In a first series of experiments vehicle (saline solution, $\mathrm{NaCl} 0.9 \%, 0.5 \mathrm{ml} \mathrm{rat}^{-1}$ ) or a saline solution of acid acetic $\left(7.5 \% \mathrm{v} \mathrm{v}^{-1}, 0.5 \mathrm{ml} \mathrm{rat}^{-1}\right)$, were intracolonically administered. Colonic motility was recorded during a $60 \mathrm{~min}$ period before the i.v. administration of vehicle or antagonists (basal pre-drug). Afterwards, vehicle (saline, $1 \mathrm{ml} \mathrm{kg}{ }^{-1}$, i.v. $)$ or nepadutant $\left(0.1 \mu \mathrm{mol} \mathrm{kg}{ }^{-1}\right.$, i.v. $)$, atropine $\left(1.4 \mu \mathrm{mol} \mathrm{kg} \mathrm{kg}^{-1}\right.$ i.v. followed by infusion of $1.4 \mu \mathrm{mol} \mathrm{ml} \mathrm{m}^{-1}$ in a volume of $300 \mu \mathrm{l} \mathrm{h}^{-1}$ ), or hexamethonium $\left(13.5 \mu \mathrm{mol} \mathrm{kg} \mathrm{kg}^{-1}\right.$ i.v. as a bolus followed by infusion of $13.5 \mu \mathrm{mol} \mathrm{m} l^{-1}$ in a volume of $300 \mu \mathrm{l} \mathrm{h}^{-1}$ ), were administered as a bolus, or as a bolus followed by continuous i.v. infusion. Colonic motility was recorded up to $120 \mathrm{~min}$ after administration of drugs.

Other experiments were carried out on distension-induced colonic motility. After recording basal colonic motility (45 min), the latex balloon was filled up with additional
$0.5 \mathrm{ml}$ of water (in order to induce a distension-induced colonic motility); the experiment followed the same protocol as described above (60 min of the new baseline with $1 \mathrm{ml}$ of distension, and the effect of drugs was recorded for further $120 \mathrm{~min})$.

In these experiments the following parameters related to colonic motility were evaluated: the area under the curve (AUC, $\mathrm{mmHg} \mathrm{s}^{-1}$ ), the maximal amplitude of contractions (MAC, $\mathrm{mmHg}$ ) and the minimal values of basal pressure $(\mathrm{MP}, \mathrm{mmHg}$ ), as differences $(\Delta)$ between sample periods of $30 \mathrm{~min}$ after and before drug administration.

In a second series of experiments, the effects of three different pharmacological treatments on the $\mathrm{NK}_{2}$ receptor selective agonist $\left[\beta \mathrm{Ala}^{8}\right] \mathrm{NKA}(4-10)$-mediated colonic contractions were evaluated: hexamethonium $\left(13.5 \mu \mathrm{mol} \mathrm{kg}^{-1}\right.$ i.v. as a bolus followed by infusion of $13.5 \mu \mathrm{mol} \mathrm{ml^{-1 }}$ in a volume of $\left.300 \mu \mathrm{l} \mathrm{h}^{-1}\right)$, atropine $\left(1.4 \mu \mathrm{mol} \mathrm{kg} \mathrm{kg}^{-1}\right.$ i.v. as a bolus followed by infusion of $1.4 \mu \mathrm{mol} \mathrm{ml}^{-1}$ in a volume of $\left.300 \mu \mathrm{h} \mathrm{h}^{-1}\right)$ and nepadutant $\left(0.1 \mu \mathrm{mol} \mathrm{kg}^{-1}\right.$ i.v. $)$. After having recorded a control response to $\left[\beta \mathrm{Ala}^{8}\right] \mathrm{NKA}(4-10)$ (10 nmol kg-1, i.v.), the $\mathrm{NK}_{2}$ receptor agonist challenge was repeated again at 5, 30, 60, 90 and 120 min after drug administration. The dose of the agonist has been selected on the basis of previous dose-response experiments where $10 \mathrm{nmol} \mathrm{kg} \mathrm{kg}^{-1}$ attained to about the $50 \%$ of the maximal contractile effect of $\left[\beta \mathrm{Ala}^{8}\right] \mathrm{NKA}(4-10)$.

Similar experiments were performed in $\mathrm{N}^{\omega}$-nitro-L-argininemethyl ester (L-NAME $1.85 \mu \mathrm{mol} \mathrm{kg}^{-1}$ i.v. as a bolus followed by infusion of $1.85 \mu \mathrm{mol} \mathrm{m} l^{-1}$ in a volume of $\left.300 \mu \mathrm{l} \mathrm{h}^{-1}\right)$ - or hexamethonium $\left(13.5 \mu \mathrm{mol} \mathrm{kg} \mathrm{kg}^{-1}\right.$ i.v. as a bolus followed by infusion of $13.5 \mu \mathrm{mol} \mathrm{m}^{-1}$ in a volume of $300 \mu \mathrm{h} \mathrm{h}^{-1}$ )-pretreated rats in order to evaluate the effect of atropine, hexamethonium, or atropine, respectively. These experiments were evaluated by comparing the basal response to the agonist, as maximal amplitude of contractions (MAC, $\mathrm{mmHg}$ ), with responses obtained in the presence of drugs at various times after their administration.

Basal responses to $\left[\beta \mathrm{Ala}^{8}\right] \mathrm{NKA}(4-10)\left(10 \mathrm{nmol} \mathrm{kg}^{-1}\right.$, i.v. $)$ from the above (controls or hexamethonium-pretreated rats) or a separate set of experiments (atropine) were also analysed in detail for $10 \mathrm{~min}$ following the agonist administration by evaluating 1 -min variations $(\Delta)$ in MP and MAC.

The doses of nepadutant $\left(0.1 \mu \mathrm{mol} \mathrm{kg}^{-1}\right)$ and atropine $\left(1.4 \mu \mathrm{mol} \mathrm{kg}^{-1}\right)$ were chosen on the basis of experiments where these compounds antagonized in a consistent and long-lasting manner the colonic contractions induced by [ $\left.\beta \mathrm{Ala}^{8}\right] \mathrm{NKA}(4-10) \quad\left(0.01-300 \mathrm{nmol} \mathrm{kg}{ }^{-1}\right)$ and metacholine (0.001-30 $\mu \mathrm{mol} \mathrm{kg} \mathrm{mg}^{-1}$ ) respectively, without affecting the dose-response curve (evaluated as MAC) of metacholine and $\left[\beta \mathrm{Ala}^{8}\right] \mathrm{NKA}(4-10)$, respectively (data not shown). The dose of hexamethonium was selected according to a previous study (Maggi et al., 1986), showing that $13.5 \mu \mathrm{mol} \mathrm{kg}^{-1}$ was the maximal dose (as bolus) devoid of effects on contractions of skeletal muscle in rats. The infusion was necessary to maintain a steady inhibition on ganglionic structures. The dose of L-NAME $\left(1.85 \mu \mathrm{mol} \mathrm{kg}^{-1}\right)$ was chosen as it reduces colonic compliance (e.g., Ciccocioppo et al., 1994), without triggering an exaggerated spontaneous motility (e.g., Mizuta et al., 1999) that renders more difficult the evaluation of motility stimulated by pharmacological means (e.g. $\left[\beta \mathrm{Ala}^{8}\right] \mathrm{NKA}(4-$ 10) (data not shown). 


\section{Data evaluation and statistical analysis}

All data in the text and figures are mean \pm standard error of the mean for the given number $(n)$ of experiments. Statistical analysis was performed by means of two-way analysis of variance for repeated measurements (Split Plot ANOVA): post hoc test (Fisher's least significant difference, LSD) was carried out when the $\mathrm{F}$ for drug treatment of the ANOVA resulted significant $(P<0.05)$. In the post hoc test, a $P$ value $<0.05$ was considered statistically significant. Differences between the incidence of high amplitude $(>15 \mathrm{mmHg})$ colonic extractions in various experimental conditions was evaluated by means of Fisher's exact test. Overall ANOVA indicated that basal values of motility parameters (both prestimulus and pre-drug) did not differ among various experimental groups within a given experiment.

\section{Drugs}

Drugs used were: atropine sulphate salt, hexamethonium bromide, $\mathrm{N}^{\omega}$-nitro-L-arginine methyl ester, $\mathrm{HCl}$ (Sigma, St. Louis, MO., U.S.A.; $\left[\beta \mathrm{Ala}^{8}\right] \mathrm{NKA}(4-10)$ and MEN 11420 ((Asn (2-AcNH- $\beta$-D-Glc)-Asp-Trp-Phe-Dap-Leu(c $\quad(2 \beta-5 \beta))$ were synthesized by conventional solid phase methods at the Chemistry Department of Menarini Ricerche (Florence, Italy).

\section{Results}

\section{Effect of hexamethonium, atropine or nepadutant on distension $(0.5$ and $1.0 \mathrm{ml})$-induced colonic motility}

The filling of the colonic balloon with $0.5 \mathrm{ml}$ evoked high amplitude $(>15 \mathrm{mmHg})$ colonic contractions only in $19 \%$ (28 out of 146) of preparations. The maximal amplitude of contractions (MAC) was $10.8 \pm 1.1 \mathrm{mmHg}$, the resting colonic tone (minimal pressure, MP) was $9.5 \pm 0.5 \mathrm{mmHg}$, and the motility index (calculated as area under the curve, AUC) resulted $3559 \pm 191 \mathrm{mmHg} \mathrm{s}(n=146)$. Except for the resting tone, which significantly declined over the time (from $12.6 \pm 1.7$ to $8.3 \pm 1.5 \mathrm{mmHg}$ in $210 \mathrm{~min}, P<0.01$ from 60 to $120 \mathrm{~min}$ ), the other motility parameters did not significantly change throughout the duration of experiments $(210 \mathrm{~min}$, i.e., $30 \mathrm{~min}$ basal pre-stimulus, plus $60 \mathrm{~min}$ basal pre-drug, plus $120 \mathrm{~min}$ post-drug) in control animals receiving an intracolonic enema of saline $(0.5 \mathrm{ml})$ (Figure 1$)$. In these experimental conditions, atropine, hexamethonium, and nepadutant had no consistent effects on MAC and AUC; only atropine slightly inhibited these parameters (Figure $2 a, b)$. This effect stems from the observation that atropine and hexamethonium inhibited motility in the minority of preparations which displayed high amplitude colonic contractions $(>15 \mathrm{mmHg})$ in response to this volume of distension. Unlike hexamethonium, both atropine and nepadutant reduced the time-dependent declining of the resting tone, i.e., they reduced the passive compliance (Figure 2c).

When the volume of the colonic balloon was augmented to $1 \mathrm{ml}$, the incidence of preparations displaying high amplitude colonic contractions $(>15 \mathrm{mmHg})$ increased from $9(0.5 \mathrm{ml})$ to $36(1 \mathrm{ml})$ out of 48 preparations tested $(P<0.01)$. As a consequence, both MAC and AUC were significantly larger

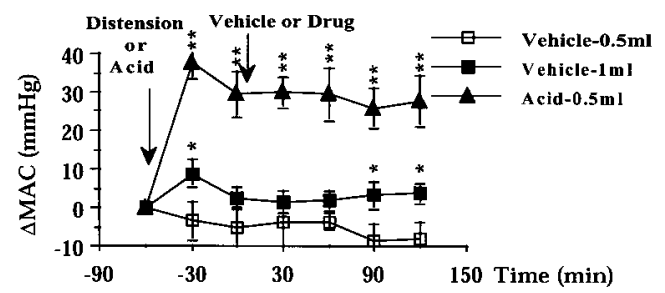

b
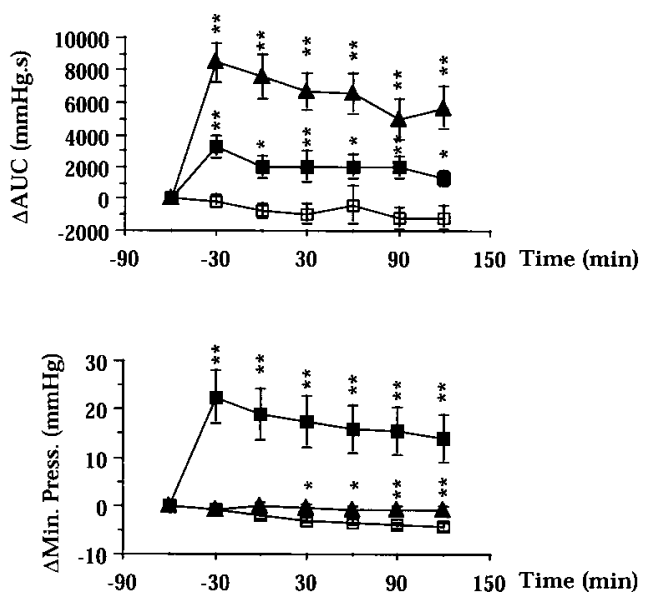

Figure 1 Effect of balloon distension $(0.5$ and $1 \mathrm{ml})$ or intraluminal acetic acid $\left(0.5 \mathrm{ml}\right.$ of $7.5 \% \mathrm{v} \mathrm{v}^{-1}$ in saline) application on colonic motility: (a) AUC, area under the curve; (b) MAC, maximal amplitude of contractions; (c) minimal pressure. Results are expressed as difference $(\Delta)$ in respect to baseline values. Fisher LSD test: $* P<0.05$ and $* * P<0.01$ vs time-matched Vehicle- $0.5 \mathrm{ml}$. Each point and bar represents the mean \pm s.e.mean of 12 experiments.

(from $12.4 \pm 1.9$ to $22.5 \pm 1.7 \mathrm{mmHg} P<0.01$ and from $2793 \pm 514$ to $\left.5292 \pm 1256 \mathrm{mmHg} \mathrm{s}^{-1} \quad P<0.01, n=48\right)$ in respect to control preparations with the colonic balloon filled with $0.5 \mathrm{ml}$ (Figure 1a,b). The MAC of preparations distended with $1 \mathrm{ml}$ showed a time-dependent decline, although this parameter still remained greater in magnitude than that in control preparations with the balloon filled of $0.5 \mathrm{ml}$ at $120-150 \mathrm{~min}$ from distension (Figure 1b). The AUC remained relatively constant during the course of experiments following the $1 \mathrm{ml}$ distension-evoked motility (Figure 1a). Colonic distension also increased resting tone (from $8.3 \pm 0.8 \mathrm{mmHg}$ at $0.5 \mathrm{ml}$ to $28.5 \pm 2.4 \mathrm{mmHg}$ at $1 \mathrm{ml}$, $n=48$ ), which however was subjected to a large timedependent decline $(22.8 \pm 4.7 \mathrm{mmHg}$, at $150 \mathrm{~min}$ from distension, $P<0.01$ ).

Both atropine and hexamethonium inhibited the distension-evoked colonic motility, and their effect resulted statistically significant on either MAC or AUC (Figure $3 \mathrm{a}, \mathrm{b})$, indicating that the $1.0 \mathrm{ml}$ distension-evoked motility is largely sustained by a cholinergic reflex mechanism. The incidence of preparations displaying high amplitude contractions decreased from 7 to $1(P<0.05)$ and from 6 to 0 $(P<0.05)$ out of 12 following atropine and hexamethonium, respectively. Nepadutant also decreased both the MAC and the AUC but these effects were not statistically significant (Figure 3a,b). Likewise, nepadutant did not change the incidence of preparations with high amplitude contractions (not shown). Neither anticholinergic drugs, nor nepadutant 

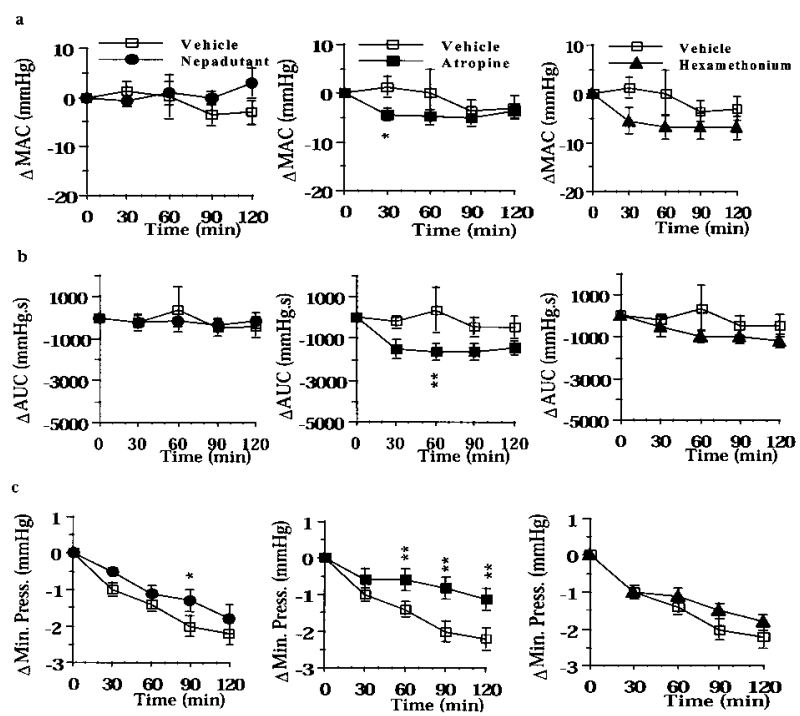

Figure 2 Effect of nepadutant $\left(0.1 \mu \mathrm{mol} \mathrm{kg}{ }^{-1}\right.$, i.v. $)$, atropine $\left(1.4 \mu \mathrm{mol} \mathrm{kg} \mathrm{kg}^{-1} \mathrm{~h}^{-1}\right)$, or hexamethonium $\left(13.5 \mu \mathrm{mol} \mathrm{kg} \mathrm{kg}^{-1} \mathrm{~h}^{-1}\right)$ on colonic motility induced by the filling of the colonic balloon with $0.5 \mathrm{ml}$ : (a) MAC, maximal amplitude of contractions; (b) AUC, area under the curve; (c) Minimal Pressure. Results are expressed as difference $(\Delta)$ in respect to baseline values. Fisher LSD test: ${ }^{*} P<0.05$ and $* * P<0.01$ vs time-matched controls. Each point and bar represents the mean \pm s.e.mean of 12 experiments.

modified the time-dependent decline of the resting tone in these conditions (Figure 3c).

\section{Effect of hexamethonium, atropine or nepadutant on acid-induced colonic motility}

In preparations with the balloon filled with $0.5 \mathrm{ml}$, the administration of an acetic acid enema $\left(0.5 \mathrm{ml}\right.$ of $7.5 \% \mathrm{v} \mathrm{v}^{-1}$, in saline) triggered a vigorous colonic motility: the incidence of preparations displaying high amplitude colonic contractions ( $>15 \mathrm{mmHg}$ ) increased from nine (before acid) to 47 (after acid) out of 48 preparations tested $(P<0.01)$. Both MAC and the AUC significantly increased (from 12.7 \pm 2.8 to $44.8 \pm 3.1 \mathrm{mmHg} \quad P<0.01$ and from $3708 \pm 455$ to $\left.11548 \pm 1208 \mathrm{mmHg} \mathrm{s}^{-1} P<0.01, n=48\right)$ in respect to control preparations (colonic balloon filled with $0.5 \mathrm{ml}$ ) which received a saline enema (Figure 1a,b). The acid-evoked colonic motility was fairly constant throughout the experimental period: only the AUC significantly declined $(P<0.01)$ at 120-150 min from the acid enema (Figure 1a). Despite this, both the AUC and the MAC were significantly increased for the whole experimental period as compared to timematched control preparations (Figure 1a,b). The colonic resting tone of acid-treated animals did not fade during the course of experiments, and therefore resulted significantly higher in respect to time-matched controls (Figure 1c).

Both atropine and hexamethonium abolished the acidinduced colonic motility, reducing both the AUC and the MAC for the whole experimental period (Figure 4a,b). The incidence of preparations displaying high amplitude colonic contractions was reduced by both atropine and hexamethonium from 11 to 3 and from 12 to 1 out of 12 , respectively $(P<0.01)$. Nepadutant also partly reduced the AUC and MAC: at the peak of its effect the AUC and MAC were inhibited by 48 and $39 \%$, respectively, as compared to controls. Nepadutant, however did not reduce the number of preparations with high amplitude colonic contractions (from 12 to 10 out of 12). Atropine and nepadutant (but not hexamethonium) also reduced the resting tone of acid-treated colons, however only the effect of atropine resulted statistically significant (Figure 4c).

\section{Effect of hexamethonium, atropine and nepadutant on $\left[\beta\right.$ Ala $\left.^{8}\right] N K A(4-10)$-induced colonic contractions in vehicle-, $L-N A M E-$, or hexamethonium-pretreated animals}

In control animals (intracolonic balloon filled with $0.5 \mathrm{ml}$ ), the administration of $\left[\beta \mathrm{Ala}^{8}\right] \mathrm{NKA}(4-10)\left(10 \mathrm{nmol} \mathrm{kg}^{-1}\right.$, i.v. $)$ induced a tonic-type colonic contraction with phasic contractions superimposed (Figure 5a). Nepadutant $\left(0.1 \mu \mathrm{mol} \mathrm{kg}{ }^{-1}\right.$, i.v.) abolished both responses, whereas atropine

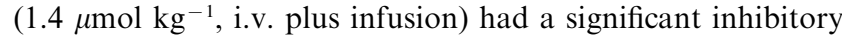
effect on the tonic but not on the phasic component of $\left[\beta \mathrm{Ala}^{8}\right] \mathrm{NKA}(4-10)$-induced contractions (Figure 5b,c). In contrast, hexamethonium (13.5 $\mu \mathrm{mol} \mathrm{kg} \mathrm{kg}^{-1}$, i.v. plus infusion) had an inhibitory effect on the phasic contractions but enhanced the tonic component of $\left[\beta \mathrm{Ala}^{8}\right] \mathrm{NKA}(4-10)$-induced contractile effect (Figure $5 b, c)$. Despite these changes in the morphology of the contractile response to the $\mathrm{NK}_{2}$ receptor agonist, hexamethonium and atropine did not significantly modify the MAC upon repeated (up to $120 \mathrm{~min}$ from their administration) $\left[\beta \mathrm{Ala}^{8}\right] \mathrm{NKA}(4-10)$ challenges (Figure 6a).

In L-NAME $\left(1.85 \mu \mathrm{mol} \mathrm{kg}{ }^{-1}\right.$, i.v. plus infusion)-pretreated animals, the MAC evoked by $\left[\beta \mathrm{Ala}^{8}\right] \mathrm{NKA}(4-10)$ increased in a time-dependent manner, with significant effects at $60-$ $120 \mathrm{~min}(P<0.05)$ as compared to time-matched control preparations. Following L-NAME pretreatment, either hexamethonium $(P<0.01$ since $30-120 \mathrm{~min})$ and atropine
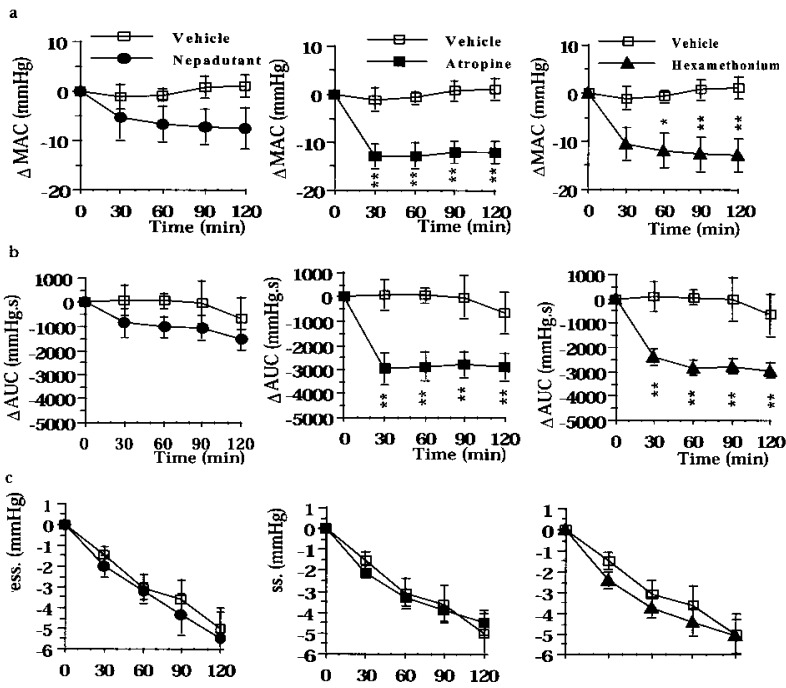

Figure 3 Effect of nepadutant $\left(0.1 \mu \mathrm{mol} \mathrm{kg}^{-1}\right.$, i.v. $)$, atropine $\left(1.4 \mu \mathrm{mol} \mathrm{kg} \mathrm{kg}^{-1} \mathrm{~h}^{-1}\right)$, or hexamethonium $\left(13.5 \mu \mathrm{mol} \mathrm{kg}{ }^{-1} \mathrm{~h}^{-1}\right)$ on intracolonic pressure induced by the filling of the colonic balloon with $1 \mathrm{ml}$ : (a) MAC, maximal amplitude of contractions; (b) AUC, area under the curve; (c) Minimal Pressure. Results are expressed as difference $(\Delta)$ in respect to baseline values. Fisher LSD test: ${ }^{*} P<0.05$ and $* * P<0.01$ vs time-matched controls. Each point and bar represents the mean \pm s.e.mean of 12 experiments. 

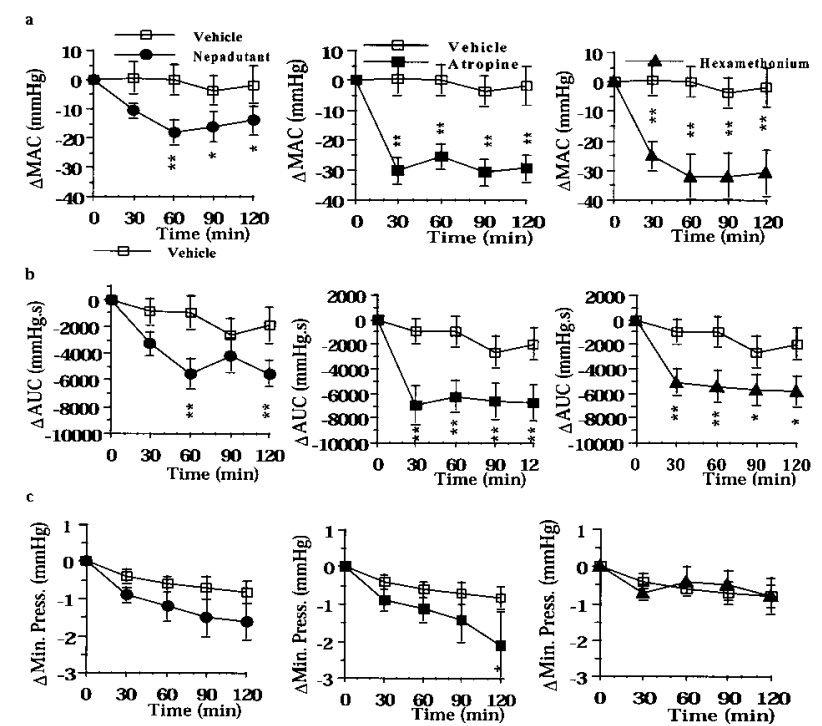

Figure 4 Effect of nepadutant $\left(0.1 \mu \mathrm{mol} \mathrm{kg}{ }^{-1}\right.$, i.v. $)$, atropine $\left(1.4 \mu \mathrm{mol} \mathrm{kg}^{-1} \mathrm{~h}^{-1}\right)$, or hexamethonium $\left(13.5 \mu \mathrm{mol} \mathrm{kg} \mathrm{kg}^{-1} \mathrm{~h}^{-1}\right)$ on intracolonic pressure induced by the filling of the colonic balloon with $0.5 \mathrm{ml}$ and luminal application of $0.5 \mathrm{ml}$ of acetic acid $7.5 \%$ $\mathrm{V} \mathrm{v}^{-1}$ in saline: (a) MAC, maximal amplitude of contractions; (b) AUC, area under the curve; (c) Minimal Pressure. Results are expressed as difference $(\Delta)$ in respect to baseline values. Fisher LSD test: $* P<0.05$ and $* * P<0.01$ vs time-matched controls. Each point and bar represents the mean \pm s.e.mean of 12 experiments.

$(P<0.05$ at $60-120 \mathrm{~min})$ reduced the MAC elicited by $\left[\beta \mathrm{Ala}^{8}\right] \mathrm{NKA}(4-10)$ (Figure 6b).

In hexamethonium pretreated-rats the MAC induced by $\left[\beta \mathrm{Ala}^{8}\right] \mathrm{NKA}(4-10)$ was slightly, but significantly decreased by atropine $(P<0.05$ at $30 \mathrm{~min}$ ) (Figure $6 \mathrm{c}$ ).

\section{Discussion}

It has been shown that $\mathrm{NK}_{2}$ receptor antagonists decrease intestinal motility in various diarrhoea models (see Introduction), and can also reduce, through a peripheral site of action, behavioural responses to colonic irritation preventing the activation of nociceptive spinal cord neurons which receive afferent input from the inflamed colon (Kiss et al., 1999; Olivar et al., 1999; Toulouse et al., 2000). The present results provide evidence for the involvement of endogenous tachykinins acting through $\mathrm{NK}_{2}$ receptors in exaggerated colonic motility associated with acute colonic irritation induced by acetic acid in rats. Tachykinins, through the stimulation of $\mathrm{NK}_{2}$ receptors, can exert both excitatory and inhibitory modulation of intestinal motility (Lecci et al., 1998; Onori et al., 2000). In vitro, the inhibition of colonic propulsion by tachykinin $\mathrm{NK}_{2}$ receptor antagonists was only partial in the absence of muscarinic antagonists supporting the concept that acetylcholine is the principal neuroeffector released from myenteric ascending excitatory motor neurons to the circular muscle (Holzer \& Maggi, 1994; Maggi et al., 1997; Tonini et al., 2001). Since tachykinins are co-stored with acetylcholine in these neurons (Brookes et al., 1991) and a tachykinergic $\mathrm{NK}_{2}$ receptor-mediated excitatory junction potential could be demonstrated in the colon (Santicioli et al., 1997), the slight inhibitory effect of $\mathrm{NK}_{2}$ receptor antagonists on peristalsis, and the synergistic inhibitory effect of these antagonists with atropine have been putatively attributed to the blockade of postjunctional (muscular) $\mathrm{NK}_{2}$ receptors (Onori et al., 2000; Tonini et al., 2001). However at concentrations having little or no effects on smooth muscle contractility, tachykinins increased the electrically-evoked, nerve-mediated, atropinesensitive contractions in the isolated rat rectum, suggesting the possibility of the presence of excitatory prejunctional tachykinin receptors on cholinergic motor neurons (Maggi et al., 1988). Indeed, recent immunohistochemical studies have shown the presence of $\mathrm{NK}_{2}$ receptors on SP-containing nerve fibres in longitudinal, circular, and deep muscular plexus: since these fibres are likely to belong to motor neurons (Vannucchi et al., 2000), and SP is co-stored with acetylcholine in these neurons, $\mathrm{NK}_{2}$ receptors could modulate the activity of motor neurons at prejunctional level.

The present findings provide several lines of evidence indicating that this modulation is excitatory and that the $\mathrm{NK}_{2}$ receptor-induced enhancement of cholinergic activity could have pathophysiological relevance during colonic irritation. First, although the contractions induced by the administration of selective $\mathrm{NK}_{2}$ receptor agonist are little affected by atropine in control preparations, an inhibitory effect could be shown in L-NAME- or hexamethoniumpretreated animals. This is likely to occur because $\mathrm{NK}_{2}$ receptor agonists can activate a nitric oxide-mediated

a
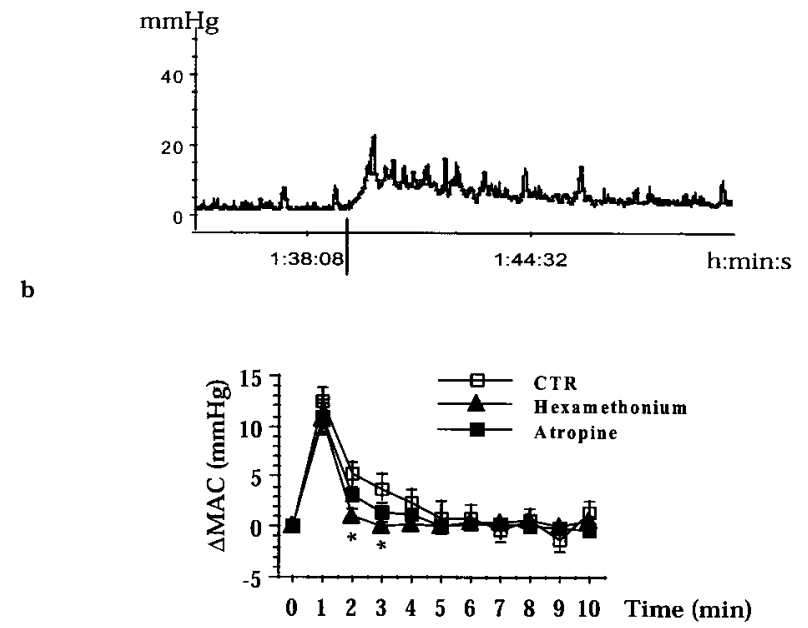

c

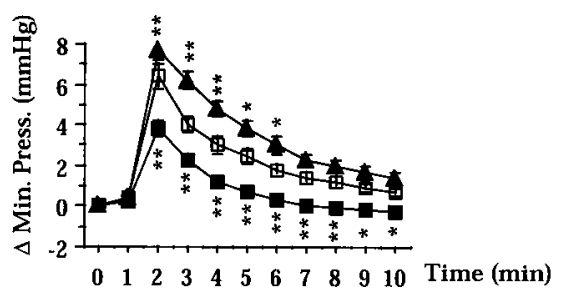

Figure 5 The effect of $\left[\beta \mathrm{Ala}^{8}\right] \mathrm{NKA}(4-10)\left(10 \mathrm{nmol} \mathrm{kg}{ }^{-1}\right.$, i.v. $)$ on colonic motility. A representative tracing (32 experiments) of the effect of $\left[\beta \mathrm{Ala}^{8}\right] \mathrm{NKA}(4-10)$ (vertical line) in control preparations (balloon filled with $0.5 \mathrm{ml}$ ) (a). $\left[\beta \mathrm{Ala}^{8}\right] \mathrm{NKA}(4-10)$ increases the amplitude of contractions (MAC) and minimal pressure. The effect of atropine $(n=16)$ or hexamethonium $(n=16)$ on MAC (b). The effect of atropine or hexamethonium on minimal pressure (c). Fisher LSD test: $* P<0.05$ and ${ }^{* *} P<0.01$ vs CTR 
a

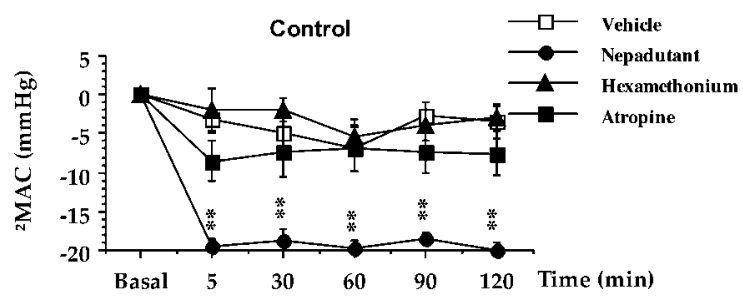

b
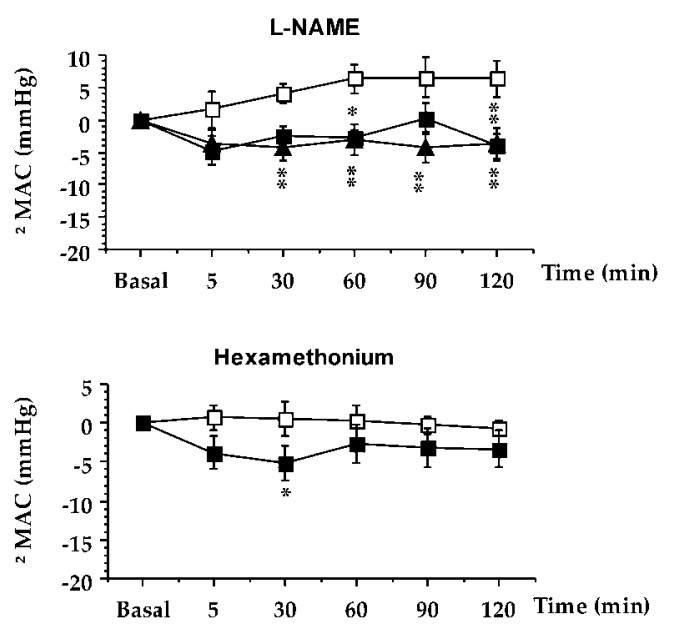

Figure 6 The effect of atropine, hexamethonium, or nepadutant on $\left[\beta \mathrm{Ala}^{8}\right] \mathrm{NKA}(4-10)\left(10 \mathrm{nmol} \mathrm{kg}{ }^{-1}\right.$, i.v. $)$-induced colonic contractions (MAC) in: vehicle-pretreated (a), L-NAME-pretreated (b), or hexamethonium-pretreated preparations (c). Each point and bar represents the mean \pm s.e.mean of $8-10$ experiments. Fisher LSD test: ${ }^{*} P<0.05$ and ${ }^{* * P} P<0.01$ vs Vehicle.

inhibitory mechanism on colonic motility (Zagorodnyuk \& Maggi, 1995) and this inhibitory mechanism is partly reduced, by hexamethonium (Onori et al., 2000). The fact that the atropine-sensitive component of the $\mathrm{NK}_{2}$ receptorevoked contraction is hexamethonium-resistant (and tetrodotoxin-resistant, see Chang et al., 1991) is in keeping with the anatomical evidence indicating that the modulation of cholinergic activity occurs at nerve terminals. This mechanism could be activated to some extent also during distensionevoked colonic motility both in vitro and in vivo since nepadutant, or other $\mathrm{NK}_{2}$ receptor antagonists, only slightly inhibit the colonic contractions which were totally ascribable to a cholinergic reflex (Holzer \& Maggi, 1994; Santicioli et al., 1997; Onori et al., 2000; Tonini et al., 2001). Likewise, the suppression of this mechanism could account for the nonsignificant inhibitory effect of nepadutant on motility when the colonic balloon was filled with $1 \mathrm{ml}$.

Colitis induced by acetic acid is associated to the appearance of migrating motor complexes (Sethi \& Sarna, 1991), which may be correlated to the acid-induced high amplitude contractions observed in the present study. These contractions, which are larger than those evoked by distension, were totally

\section{References}

BROOKES, S.J.H., STEELE, P.A. \& COSTA, M. (1991). Identification and immunohistochemistry of cholinergic and non-cholinergic circular muscle motor neurons in the guinea-pig small intestine. Neuroscience, 42, $863-878$. abolished by atropine or hexamethonium, indicating that they are totally mediated by cholinergic reflexes. The activation of $\mathrm{NK}_{2}$ receptors largely supports the enhancement of cholinergic activity during colonic irritation since nepadutant consistently reduced acetic acid-induced colonic motility. Since, previous studies have determined that low doses of NKA enhances the intestinal transit in an atropine-sensitive manner (Holzer, 1985), acetic acid-induced colonic motility could also be associated to an increased propulsive function (Myers et al., 1997) thus contributing to the symptoms of diarrhoea (Croci et al., 1997; Makridis et al., 1999).

An excitatory cholinergic contribution to the resting colonic tone was detected in atropine-treated animals following colonic irritation but not following distension. Apparently, this contribution does not involve the nicotinic activation of motor neurons since hexamethonium did not mimick the effect of atropine. However the possibility that hexamethonium blocks both excitatory and inhibitory modulations of colonic tone cannot be excluded. Although not statistically-significant, the fact that nepadutant produces a relaxant effect similar to atropine, suggests that cholinergic motor neurons are somehow involved in increasing colonic tone during inflammation. In contrast, in control preparations having the colonic balloon filled with $0.5 \mathrm{ml}$, both atropine and nepadutant increased the resting colonic tone (i.e., they reduced passive compliance). A reduction of compliance by muscarinic and $\mathrm{NK}_{2}$ receptor antagonists has already been described during peristalsis in isolated intestinal segments (Holzer \& Maggi, 1994). This effect could be putatively attributed to an increased resistance of intraluminal flow due to an impairment of the peristalsis induced by atropine or $\mathrm{NK}_{2}$ receptor antagonists. However, since in our set-up the reduction of passive compliance (the colonic balloon could not be propulsed) was observed in the absence of a consistent activation of excitatory motor neurons, the above hypothesis is unlikely. Since both muscarinic (Marino et al., 1997) and $\mathrm{NK}_{2}$ receptor agonists (Giuliani et al., 1988) can respectively activate intrinsic and extrinsic sympathetic mechanisms in the intestine, the decrease in passive compliance could be attributed to a reduction of sympathetic tone, however this possibility contrasts with the reduction of compliance by $\mathrm{NK}_{2}$ receptor antagonist in isolated intestinal segments (Holzer \& Maggi, 1994). As mentioned in the introduction, since $\mathrm{NK}_{2}$ receptors are expressed on NOS-containing inhibitory interneurons (Portbury et al., 1996), both nepadutant (Zagorodnyuk \& Maggi, 1995; Onori et al., 2000) and atropine (Johnson et al., 1996) could decrease colonic compliance by reducing excitatory synaptic inputs to inhibitory motor neurons.

In conclusion, the present results provide evidence for a prejunctional excitatory modulation of cholinergic motor neurons by tachykinins acting through $\mathrm{NK}_{2}$ receptors. This modulation is amplified during acute colonic irritation and contributes to enhanced colonic motility in this condition.

CHANG, F.Y., SHARP, D. \& OUYANG, A. (1991). Multiple neurokinin receptor subtypes are present in the colon of cat and rat. Ann. NY Acad. Sci., 632, $374-376$. 
CICCOCIOPPO, R., ONORI, L., MESSORI, E., CANDURA, S.M., COCCINI, T. \& TONINI, M. (1994). Role of nitric oxide-dependent and -independent mechanisms in peristalsis and accommodation in the rabbit distal colon. J. Pharmacol. Exp. Ther., 270, 929937.

CROCI, T., EMONDS-ALT, X. \& MANARA, L. (1994). SR 48968 selectively prevents faecal excretion following activation of tachykinin NK2 receptors in rats. J. Pharm. Pharmacol., 46, $383-385$.

CROCI, T., LANDI, M., EMONDS-ALT, X., LE FUR, G., MAFFRAND, J.-P. \& MANARA, L. (1997). Role of tachykinins in castor oil diarrhoea in rats. Br. J. Pharmacol., 121, 375-380.

GiUliani, S., LECCI, A., GIACHETTI, A. \& MAGGI, C.A. (1993). Tachykinins and reflexly evoked atropine-resistant motility in the guinea-pig colon in vivo. J. Pharmacol. Exp. Ther., 265, $1224-$ 1231.

GiUliani, S., MAGgi, C.A., Rovero, P. \& Meli, A. (1988). Neurokinins induce a relaxation of rat duodenum in vivo by activating postganglionic sympathetic elements in prevertebral ganglia: involvement of an NK2 type of neurokinin receptors. $J$. Pharmacol. Exp. Ther., 246, $322-327$.

GIULIANI, S., TRAMONTANA, M., LECCI, A. \& MAGGI, C.A. (1996). Tachykinin receptor mediate atropine-resistant rat duodenal contractions in vivo. Naunyn-Schmiedeberg's Arch. Pharmacol., 354, $327-335$.

GRADY, E.F., BALUK, P., BOHM, S., GAMP, P.D., WONG, H., PAYAN, D.G., ANSEL, J., PORTBURY, A., FURNESS, J.B., MCDONALD, D.M. \& BURNETT, N.W. (1996). Characterization of antisera specific to NK1, NK2, and NK3 neurokinin receptors and their utilization to localize receptors in the rat gastrointestinal tract. $J$. Neurosci., 16, 6975-6986.

HOLZER, P. (1985). Stimulation and inhibition of gastrointestinal propulsion induced by substance $\mathrm{P}$ and substance $\mathrm{K}$ in the rat. $\mathrm{Br}$. J. Pharmacol., 86, 305-312.

HOLZER, P. \& HOLZER-PETSCHE, U. (1997). Tachykinins in the gut. Part I. Expression, release and motor function. Pharmacol. Ther. 73, $173-217$

HOLZER, P., LIPPE, I.T.H., HEINEMANN, A. \& BARTHO, L. (1998). Tachykinin NK1 and NK2 receptor-mediated control of peristaltic propulsion in the guinea-pig small intestine in vitro. Neuropharmacology, 37, 131-138.

HOLZER, P. \& MAGGI, C.A. (1994). Synergistic role of muscarinic acetylcholine and tachykinin NK2 receptors in intestinal peristalsis. Naunyn Schmiedeberg's Arch. Pharmacol., 349, $194-$ 201.

JOHNSON, P.J., BORNSTEIN, J.C., YUAN, S.Y. \& FURNESS, J.B. (1996). Analysis of contributions of acetylcholine and tachykinins to neuro-neuronal transmission in motility reflexes in the guinea-pig ileum. Br. J. Pharmacol., 118, 973-983.

KISS, S., LECCI, A., DE GROAT, W.C., MAGGI, C.A. \& BIRDER, L.A. (1999). The effect of the NK2 receptor antagonist, MEN11420 on proto-oncogene expression following experimental colitis. Soc. Neurosci. Abs., 25, 411.

LECCI, A., GIULIANI, S., TRAMONTANA, M., DE GIORGio, R. \& MAGGI, C.A. (1998). The role of tachykinin NK1 and NK2 receptors in atropine-resistant colonic propulsion in anaesthetized guinea-pigs. Br. J. Pharmacol., 124, 27-34.

LECCI, A., TRAMONTANA, M., GIULIANI, S. \& MAGGI, C.A. (1997). Role of tachykinin NK1 and NK2 receptors on colonic motility in anaesthetized rats: effect of agonists. Can. J. Physiol. Pharmacol., 75, 582-586.

MAGGI, C.A. (1995). Tachykinins and calcitonin gene-related peptide (CGRP) as co-transmitters released from peripheral endings of sensory nerves. Prog. Neurobiol., 45, $1-98$.

MAGGI, C.A., GIULIANI, S., SANTICIOLI, P., PATACCHINI, R. \& MELI, A. (1988). Neural pathways and pharmacological modulation of defecation reflex. Gen. Pharmacol., 19, 517-523.
MAGGI, C.A., GIULIANI, S. \& ZAGORODNYUK, V. (1997). Sequential activation of the triple excitatory transmission to the circular muscle of the guinea-pig colon. Neuroscience, 79, $263-274$.

MAGGI, C.A., SANTICIOLI, P. \& MELI, A. (1986). The nonstop transvesical cystometrogram in urethane-anesthetized rats: a simple procedure for quantitative studies on the various phases of urinary bladder voiding cycle. J. Pharmacol. Meth., 15, 157- 167.

MAKRIDIS, C., THEODORSSON, E., AKERSTROM, G., OBERG, K. \& KNUTSON, L. (1999). Increased intestinal non-substance $P$ tachykinin concentrations in malignant midgut carcinoid disease. J. Gastroenterol. Hepatol., 14, 500-507.

MARINO, F., COSENTINO, M., DE PONTI, F., GIARONI, C., SOMAINI, L., BOMBELLI, R., FERRARI, M., AASEN, A.J., LECCHINI, S. \& FRIGO, G. (1997). Muscarinic modulation of endogenous noradrenaline release from adrenergic terminals in the guinea-pig colon. J. Auton. Pharmacol., 17, 365-372.

MIZUTA, Y., TAKAHASHI, T. \& OWYANG, C. (1999). Nitrergic regulation of colonic transit in rats. Am. J. Physiol., 277, G275G279.

MYERS, B.S., DEMPSEY, D.T., YASAR, S., MARTIN, J.S., PARKMAN, H.P. \& RYAN, J.P. (1997). Acute experimental distal colitis alters colonic transit in rats. J. Surg. Res., 69, 107-112.

OLIVAR, T., LAIRD, J.M.A., MAGGI, C.A. \& CERVERO, F. (1999). Visceral pain and referred hyperalgesia in rats with colonic inflammation: role of tachykinins. Soc. Neurosci. Abs., 25, 681.

ONORI, L., AGGIO, A., TADDEI, G. \& TONINI, M. (2000). Contribution of NK2 tachykinin receptors to propulsion in the rabbit distal colon. Am. J. Physiol., 278, G137-G147.

PORTBURY, A.L., FURNESS, J.B., SOUTHWELL, B.R., WONG, H., WALSH, J.H. \& BUNNETT, N. (1996). Distribution of neurokinin2 receptors in the guinea-pig intestinal tract. Cell Tissue Res., 286, $281-292$.

SANTICIOLI, P., GIULIANI, S., PATACCHINI, R., TRAMONTANA, M., CRISCUOLI, M. \& MAGGI, C.A. (1997). MEN11420, a potent and selective tachykinin NK2 receptor antagonist in the guineapig and human colon. Naunyn-Schmiedeberg's Arch. Pharmacol., 356, $678-688$.

SETHI, A.K. \& SARNA, S.K. (1991). Colonic motor activity in acute colitis in conscious dogs. Gastroenterology, 100, 954-963.

TONINI, M., SPELTA, V., DE PONTI, F., DE GIORGIO, R., D'AGOSTINO, G., STANGHELLINI, V., CORINALDESI, R., STERNINI, C. \& CREMA, F. (2001). Tachykinin-dependent and independent components of peristalsis in the guinea pig isolated distal colon. Gastroenterology, 120, $938-945$.

TOUlOUSE, M., COELHO, A.M., FIORAMONTI, J., LECCI, A., MAGGI, C.A. \& BUENO, L. (2000). Role of tachykinin NK2 receptors in normal and altered rectal sensitivity in rats. $B r . J$. Pharmacol., 119, $193-199$.

TRAMONTANA, M., MAGGI, C.A. \& EVANGELISTA, S. (1994). Spasmolytic effect of the NK2 receptor selective antagonist MEN 10,627 in rat small intestine. Jpn. J. Pharmacol., 65, 281 283.

VANNUCCHI, M.-G., CORSANI, L. \& FAUSSONE-PELLEGRINI, M.-S. (2000). Co-distribution of NK2 tachykinin receptors and substance $\mathrm{P}$ in nerve endings of guinea-pig ileum. Neurosci. Lett., 287, $71-75$.

ZAGORODNYUK, V. \& MAGGI, C.A. (1995). Neuronal tachykinin receptors mediate release of non-adrenergic non-cholinergic inhibitory transmitters in the circular muscle of the guinea-pig colon. Neuroscience, 69, 643-650.

(Received March 5, 2001 Revised May 3, 2001 Accepted May 10, 2001) 